\title{
The Effect of Entrepreneurial Orientation on Business Performance: A Comparative Study of Necessity and Opportunity Entrepreneurs by Gender
}

Jean Bosco Ndikubwimana

University of Rwanda https://orcid.org/0000-0001-5154-8218

Alice Mukasekuru ( $\nabla$ amukasekuru@gmail.com )

University of Rwanda

Idrissa Ndizeye

University of Rwanda

Josephine Mutesi

University of Rwanda

Eugenie Byukusenge

University of Rwanda

Research Article

Keywords: Entrepreneurial Orientation, Women and Men, Business Performance

Posted Date: September 22nd, 2020

DOI: https://doi.org/10.21203/rs.3.rs-73718/v1

License: (c) (i) This work is licensed under a Creative Commons Attribution 4.0 International License.

Read Full License 


\title{
THE EFFECT OF ENTREPRENEURIAL ORIENTATION ON BUSINESS PERFORMANCE: A COMPARATIVE STUDY OF NECESSITY AND OPPORTUNITY ENTREPRENEURS BY GENDER.
}

\author{
${ }^{1}$ Alice MUKASEKURU (amukasekuru@ gmail.com ), ${ }^{1}$ Idrissa NDIZEYE \\ (ndizeyeidrissa123@gmail.com ), ${ }^{1}$ Ndikubwimana Jean Bosco (ndikujeanbosco@gmail.com ), ${ }^{1}$ \\ Josephine MUTESI (mutejose05@gmail.com ), ${ }^{1}$ Byukusenge Eugenie \\ (eugbyukusenge@gmail.com) \\ ${ }^{1}$ University of Rwanda, College of Business and Economics, Huye Campus
}

\begin{abstract}
Entrepreneurship is known, contribute to the economic growth locally as well as globally. To make entrepreneurship play its economic role, entrepreneurs are oriented by different factors and perform differently in their business. This lead the researchers to investigate the entrepreneurial orientation considering necessity and opportunity factors among women and men business owners and their owned businesses in Huye District. This was done to find out the effect of such orientation on their business performance and to examine the significance of cross-gender differences with regard to the variables under study. For achieving the above objectives; structured questionnaire and documentary review techniques were used to collect data. From total population of 1787 business owners identified from 11 sectors in Huye District, researchers sampled 327 respondents. Random and convenience sampling techniques were used. The results showed that both males and females are more opportunity oriented than necessity oriented. Study shows that business owned by males perform better than business owned by females regarding both financial and non-financial performance aspects. It was also found out that there are no significant differences in both levels of entrepreneurial orientation and business performance across gender. Correlation analysis revealed a significant relationship between entrepreneurial orientation of women and men business owners and their business performance. Based on these findings, it recommends that the Government of Rwanda (GoR) should focus training and sensitization for women to increase their involvement in business and improve the performance of existing women business owners. Improving entrepreneurship program by MINEDUC should
\end{abstract}


also be given consideration especially at primary and secondary levels/educations to prepare potential entrepreneurs.

Key words: Entrepreneurial Orientation, Women and Men, Business Performance.

\section{Introduction}

Entrepreneurs have been recognized as key contributors to the local and global economic growth of most countries because they are major source of business development and growth, as well as new job creation (Allen et al., 2007; Fischer et al., 1993). Researchers have found that the proportion of male opportunities in entrepreneurship surpasses that of women and free market forces continue to place women at a disadvantage in the entrepreneurial market (Alsos and Ljunggren, 1998; Anna et al., 2000).

Studies identifying the relative gender gaps in business performance are consistent globally, though not in their magnitude (Allen et al., 2007; OECD, 2005; Reynolds, Bygrave Autio, 2004). They further said that women business owners manage smaller businesses than men, they rarely have employees, and the growth of their businesses is slow and to a lower level. The difference between the businesses owned by men and those owned by women appears in the latter's lower levels of capitalization in their firms and their businesses' lower annual revenues (Belcourt, 1990; Gatewood, Shaver Gartner, 1995).

Rwanda is considered as one of the sub-Saharan African countries that has a grip on gender equality and entrepreneurship as a major tool in job creation which lead to poverty eradication, hence making female enterprises to be highly considered (Mutarindwa and Shema, 2017). Despite the above consideration, the number of women in entrepreneurship in Rwanda is less

compare to the other activities, this is evident as 42 percent of the enterprises are owned by women of which 58 percent are in informal and these businesses accounts for 30 percent of gross domestic product (GDP) (Mutarindwa and Shema, 2017). 
Entrepreneurship literature revealed that there is little theoretical and empirical work that has been offered to explain the mechanism through which entrepreneurial orientation affect business performance. Although there exist empirical explorations of gender and entrepreneurial orientations and their effects on business performance, there has not been any research conducted on gender and entrepreneurial orientation and business performance in Rwanda.

Existing studies have argued that women have largely been drawn into entrepreneurship to be rewarded, work-life balance, independence and flexibility, (opportunity-driven circumstances), on the other hand, others argue that women have been pushed into entrepreneurship due to restructuring and downsizing, which have reduced the availability of secure jobs in the labor market (necessity-driven circumstances) (Kariv,2011). Therefore, this research intends to explore the entrepreneurial orientation of women vs men business owners in Huye district and its impact on their business performance. In this way we hope to explain the factors that enhance business owners' performance in the perspective of opportunity/ neccessity entrepreneurship. This study will further establish the relationship between entrepreneurial orientations and the business performance of men and women owned businesses in Rwanda particularly Huye district.

\section{Literature Review}

\section{Opportunity- and necessity-driven entrepreneurial orientation}

GEM defines two types of entrepreneurship: opportunity based and necessity based. In general, nations with high per capita income have proportionately less necessity-pushed entrepreneurial activity and more opportunity-pulled entrepreneurial activity and vice versa for nations with low income. People in higher-income nations tend to have more opportunities for employment and stronger safety nets like social welfare programs, especially for the out-of-work; hence, proportionately fewer are pushed into entrepreneurship to support themselves and their families (Filion, 2005).

A possible explanation is that, as a nation makes the transition from a less developed nation to a developing one, there are more opportunities for employment with established businesses, so entrepreneurship, especially the necessity-driven form, declines. Entrepreneurial activity bottoms 
out and then increases again as more and more opportunities, particularly in service and knowledge-based industries, are spotted by entrepreneurs with the skills and motivation to develop them.

Entrepreneurial orientation driven by 'Opportunity' and 'necessity' has their origin from both country and individual level. Kirzner (1973) stress that "opportunity entrepreneurs are viewed as those who start a business because they are motivated or enthused to launch a venture and foresee the benefits of entrepreneurship in terms of personal and economic independence, whereas necessity entrepreneurship is more requirement based and typifies individuals who embark upon entrepreneurship out of limited or no suitable alternatives in the labor market". In most cases, opportunity entrepreneurs have other employment alternatives, some exposed to low risky or more stable than entrepreneurship (Allen et al., 2007; Langowitz and Allen, 2006); while necessity entrepreneurs have limited or no job opportunities, are experiencing unsatisfactory severe job conditions in their current employment (Langowitz and Allen, 2006; Riverin and Filion, 2005).

Through the years, these entrepreneurial-orientation types have been attached to macro-related factors at the country level, i.e., push-pull factors (Kariv et al., 2009; Ritsilä and Tervo, 2002)Pull factors are related to an opportunity driven orientation, and are seen as the environmental factors that prompt the desire to gain more from the entrepreneurial path; they are often seen as a way of achieving upward mobility and of accelerating socioeconomic status for example, making money, being independent, and tracking their work towards their interests (De Freitas, 1991).

On the other hand, push factors are associated with macro-level factors that produce a necessitydriven orientation and are seen as the invisible barriers facing individuals' career advancement prospects in the corporate world (Kariv,2011). The most common opportunity-hindering factors found in the research are unemployment, under-employment (Ritsilä and Tervo, 2002), discrimination in the labor market or in a prior job, severe dissatisfaction in a prior/current job with respect to future career opportunities, and unrewarding relationships with co-workers, 
among others. Thus, push factors force the individual to take some action that involves inherently higher risk, such as starting a business that may eliminate the experienced discrimination or dissatisfaction, and that would not be an alternative under normal circumstances (Bates, 1997; De Freitas, 1991).

Bygrave Z. (2011) asserts that entrepreneurs have a higher internal locus of control than non entrepreneurs, which means that they have a stronger aspiration to be in control of their own destiny. This has been confirmed by many surveys in which entrepreneurs said independence was a very important reason for starting their businesses. The main reasons they gave were independence, financial success, self-realization, recognition, innovation, and roles (to continue a family tradition, to follow the example of an admired person, to be respected by friends). Men rated financial success and innovation higher than women did. Interestingly, the reasons that nascent entrepreneurs gave for starting a business were similar to the reasons given by nonentrepreneurs for choosing jobs. Sometimes the person has been passed over for a promotion or even laid off or fired. The author further said that, business started by men require more capital than those started by women; a partial explanation is that women are more likely than men to start necessity-pushed businesses, which are more likely to be consumer-oriented and less likely to be business services. A business started out of necessity is as a result of an entrepreneur who cannot find a better source of income through employment where as opportunity entrepreneurship is pursuit of a new venture because it is perceived as better than remaining in one's current job or other jobs that might be available.

Necessity/opportunity orientations at the country level are evidenced through a variety of factors, such as: activation of governmental programs and policies, training facilities, publicrelated financial support, coordination and networking facilities (Hessels, van Gelderen T hurik, 2008) and, most importantly, by market attitudes towards entrepreneurship which craft these orientations at the individual level, including among men versus women (Brush et al., 2006c; Langowitz and Allen, 2006; Minniti, 2005). Different setups well developed in order to encourage women to participate in entrepreneurship, such as gender equality policies, law and 
regulations all with purpose of building and sustaining a conducive environment which is supportive of women in a business (Bruton et al. 2010 cited by Mutarindwa and Shema, 2017).

Government support initiatives like infrastructure, regulation and a legal environment have been emphasized for increasing the creation and growth of female entrepreneurship (Cho and Honorati, 2014). For insistence the Rwandan government provides diverse programs and incentives for entrepreneurs such as Business Development Fund (BDF) which gives guarants fund to women, youth and people with disabilities who have viable business plan. Also National employment Program (NEP) is another initiative from government of Rwanda that provides short term hands on training to youth and women which will enable them to create employment through entrepreneurship development (GoR, 2014). In addition to that, the government of Rwanda is doing its best in extending financial services to low income people hence financial inclusion through Savings and Credit Cooperatives (SACCO).

In a nut shell, a nation's gender equality policies, laws and regulations aimed at constructing and maintaining an environment that is both accommodating and supportive of women lead to a positive impact on their participation in entrepreneurship (Bruton et al., 2010; Klyver et al., 2013).

\section{Business performance}

Businesses with entrepreneurial orientation have the capacity to discover and exploit new market opportunities (Wiklund \& Sheperd, 2003). Research has employed a variety of financial measures like cash flow, return on assets and return on equity to assess firm performance. Some studies also suggest a combination of financial and non-financial measures which offers more comprehensive evaluation on a firm's performance (Li et al 2009). Subjective non-financial measures include, among others, perceived market share, perceived sales growth, customer satisfaction, loyalty and brand equity (Li et al, 2009, Murphy, Trailer and Hill (1996).

Radipere S., (2014) found that business performance have been measured by growth may be more accurate and accessible. He said that, for capturing different aspects of business 
performance, it is better to combine financial performance and growth such as business income, business profit, market share, return on investment, number of employees and product line.

Cooper and Gascon (1992) identified individual factors influencing performance as experience, education, occupation of parents, gender, race, age and the entrepreneur's goals. Studies of individual factors influencing performance are common. Business performance is also an outcome that all entrepreneurs must address. Entrepreneurial orientation has little attention in the entrepreneurship literature although is found to be an important determinant of many life and outcomes (Bandura, 1997).

\section{Relationship between Entrepreneurial Orientation and Business Performance}

Entrepreneurial orientation and its effect on business performance have been painted in theoretical discussions and empirical research. Entrepreneurial orientation at theoretical level is said to have positive correlation on business performance because firms with this strategic stance have advantage and are able to capitalize on emerging opportunities (Wiklund \& Sheperd, 2003). Past studies at empirical level have shown a positive relationship between entrepreneurial orientation and firm performance, for example a longitudinal study have found that entrepreneurial orientation to have long term effect on growth and financial performance of small businesses (Wiklund \& Sheperd, 2003).

\section{Research methodology}

\subsection{Research objectives}

The methodology briefly given is intended to help achieve the following objectives:

1. Explore the entrepreneurial orientation of women and men business owners and their owned business performance.

2. To examine if there are differences in the levels of entrepreneurial orientation.

3. To examine if there are cross-gender differences in the levels of business performance. 
4. To analyse the relationship between the levels of entrepreneurial orientation of business owners and their owned business performance.

\subsection{Research hypotheses}

1. There are no significant differences in the levels of entrepreneurial orientation across gender.

2. There are no significant differences in the levels of business performance across women and men owned businesses.

3. There is no significant relationship between the levels of entrepreneurial orientation of business owners and the levels of their owned business performance.

\subsection{Population and sampling techniques}

The population of the current study comprises 1787 business owners' entrepreneurial orientation identified from 11 sectors out of 14 sectors found in Huye District. Business owners from 11 sectors were targeted because the information available as per official list from HUYE District office was limited to those sectors. The sample of 327 respondents was determined, at $5 \%$ of margin error and a $95 \%$ level of confidence, using the 1970 Kreijce and Morgan's model. To select respondents, random and convenience sampling techniques were combined. The table below indicates more details about population and sample determination.

Table 1: Population and sample determination

\begin{tabular}{|l|r|r|r|r|l|r|}
\hline & \multicolumn{4}{|c|}{ Population } & \multicolumn{3}{|c|}{ Sample } \\
\cline { 2 - 8 } Sectors & Females & Males & Total & Females & Males & Total \\
\hline Gishamvu & 9 & 20 & 30 & 2 & 3 & 5 \\
\hline Karama & 0 & 0 & 0 & 0 & 0 & 0 \\
\hline Kigoma & 41 & 101 & 142 & 8 & 18 & 26 \\
\hline Kinazi & 20 & 29 & 49 & 4 & 5 & 9 \\
\hline Maraba & 8 & 10 & 18 & 1 & 2 & 3 \\
\hline Mbazi & 31 & 76 & 107 & 6 & 14 & 20 \\
\hline Mukura & 125 & 81 & 206 & 23 & 15 & 38 \\
\hline Ngoma & 317 & 395 & 712 & 58 & 72 & 130 \\
\hline Ruhashya & 15 & 39 & 54 & 3 & 7 & 10 \\
\hline Huye & 0 & 0 & 0 & 0 & 0 & 0 \\
\hline Rusatira & 22 & 58 & 80 & 4 & 11 & 15 \\
\hline
\end{tabular}




\begin{tabular}{|l|r|r|r|r|r|r|} 
Rwaniro & 0 & 0 & 0 & 0 & 0 & 0 \\
\hline ISimbi & 32 & 65 & 97 & 6 & 12 & 18 \\
\hline Tumba & 104 & 188 & 292 & 19 & 34 & 53 \\
\hline Total & 716 & 1071 & 1787 & 132 & 194 & 327 \\
\hline
\end{tabular}

Source: Researchers based on data from Huye District Archives, (2019)

\subsection{Data and data collection techniques}

Structure questionnaire and documentary review techniques were used to collect data. The questionnaires used included both close-ended questions and open-ended statements on a 5 point Likert Scales. Against each statement, respondents were required to indicate their position on the scales.

\subsection{Tools of analysis}

The Statistical Package for Social Sciences (SPSS) software was used to analysed collected data. Through this software, descriptive statistics including frequencies, percentages and mean were obtained and used to present the results. Added to that, correlation analysis was used to examine the relationship between variables while ANOVA was used to test the significance of differences.

\section{Presentation, interpretation and discussion of results}

\subsection{Profile of respondents}

Table 2: Respondents' profile

\begin{tabular}{|c|c|c|c|c|c|c|c|}
\hline \multirow[t]{2}{*}{$\begin{array}{l}\text { Profile } \\
\text { indicators }\end{array}$} & \multirow[t]{2}{*}{ Item } & \multicolumn{3}{|c|}{ Males } & \multicolumn{3}{|c|}{ Females } \\
\hline & & Frequency & $\%$ & $\begin{array}{l}\text { Cumulative } \\
\%\end{array}$ & Frequency & $\%$ & $\begin{array}{l}\text { Cumulative } \\
\%\end{array}$ \\
\hline \multirow[t]{2}{*}{ Gender } & Male & 195,00 & 59,63 & & & & \\
\hline & Female & & & & 132,00 & 39,37 & \\
\hline \multirow{5}{*}{ Age } & $18-25$ & 35,00 & 17,95 & 18,00 & 35,00 & 26,51 & 26,51 \\
\hline & $26-35$ & 96,00 & 49,23 & 67,00 & 61,00 & 46,21 & 72,72 \\
\hline & $36-45$ & 37,00 & 19,00 & 86,00 & 21,00 & 15,91 & 88,63 \\
\hline & $46-55$ & 21,00 & 10,77 & 97,00 & 13,00 & 9,85 & 98,48 \\
\hline & over 55 & 6,00 & 3,08 & 100,00 & 2,00 & 1,52 & 100,00 \\
\hline \multirow{4}{*}{$\begin{array}{l}\text { Educational } \\
\text { qualification }\end{array}$} & None & 14,00 & 7,18 & 7,00 & 11,00 & 8,33 & 8,33 \\
\hline & Primary & 85,00 & 43,59 & 51,00 & 32,00 & 24,24 & 32,57 \\
\hline & Secondary & 61,00 & 31,28 & 82,00 & 56,00 & 42,43 & 75,00 \\
\hline & Undergraduate & 30,00 & 15,38 & 97,00 & 21,00 & 15,91 & 90,91 \\
\hline
\end{tabular}




\begin{tabular}{|c|c|c|c|c|c|c|c|}
\hline & Postgraduate & 2,00 & 1,03 & 98,00 & 7,00 & 5,3 & 96,21 \\
\hline & Other & 3,00 & 1,54 & 100,00 & 5,00 & 3,79 & 100,00 \\
\hline \multirow{4}{*}{ Marital status } & Single & 72,00 & 36,92 & 37,00 & 30,00 & 22,73 & 23,00 \\
\hline & Maried & 117,00 & 60,00 & 97,00 & 93,00 & 70,45 & 93,00 \\
\hline & Divoced & 2,00 & 1,03 & 98,00 & 8,00 & 6,06 & 99,00 \\
\hline & Widowed & 4,00 & 2,05 & 100,00 & 1,00 & 0,76 & 100,00 \\
\hline \multirow{6}{*}{ Business sector } & Service & 28,00 & 14,36 & 14,00 & 25,00 & 18,94 & 18,94 \\
\hline & Production & 2,00 & 1,03 & 15,00 & 3,00 & 2,27 & 21,21 \\
\hline & \begin{tabular}{|l|} 
Agriculture \\
\end{tabular} & 7,00 & 3,59 & 19,00 & 5,00 & 3,79 & 25,00 \\
\hline & Trade & 141,00 & 72,31 & 91,00 & 89,00 & 67,42 & 92,42 \\
\hline & Hand craft & 15,00 & 7,69 & 99,00 & 8,00 & 6,06 & 98,48 \\
\hline & Other & 2,00 & 1,03 & 100,00 & 2,00 & 1,52 & 100,00 \\
\hline \multirow{3}{*}{$\begin{array}{l}\text { Business legal } \\
\text { status }\end{array}$} & Sole proprietorship & 185,00 & 94,87 & 95,00 & 127,00 & 96,21 & 96,00 \\
\hline & Partnership & 8,00 & 4,10 & 99,00 & 5,00 & 3,79 & 100,00 \\
\hline & Corporation & 2,00 & 1,03 & 100,00 & 0,00 & 0,00 & 100,00 \\
\hline \multirow{2}{*}{$\begin{array}{l}\text { Business } \\
\text { location }\end{array}$} & Home & 30,00 & 15,38 & 15,00 & 24,00 & 18,18 & 18,00 \\
\hline & Rented premise & 165,00 & 84,62 & 100,00 & 108,00 & 81,82 & 100,00 \\
\hline \multirow{5}{*}{$\begin{array}{l}\text { Period in the } \\
\text { business }\end{array}$} & Less than a year & 34,00 & 17,44 & 17,44 & 37,00 & 28,03 & 28,00 \\
\hline & $2-3$ years & 36,00 & 18,46 & 35,90 & 31,00 & 23,48 & 51,00 \\
\hline & 3-4 years & 32,00 & 16,41 & 52,31 & 22,00 & 16,67 & 68,00 \\
\hline & $4-5$ years & 22,00 & 11,28 & 63,59 & 9,00 & 6,82 & 75,00 \\
\hline & over 5 years & 71,00 & 36,41 & 100,00 & 33,00 & 25,00 & 100,00 \\
\hline \multirow{5}{*}{$\begin{array}{l}\text { Origin of } \\
\text { business } \\
\text { advice }\end{array}$} & Business parter(s) & 15,00 & 7,77 & 8,00 & 16,00 & 12,12 & 12,00 \\
\hline & Husband & 21,00 & 10,88 & 19,00 & 45,00 & 34,09 & 46,00 \\
\hline & Bank & 18,00 & 9,33 & 28,00 & 7,00 & 5,30 & 51,00 \\
\hline & Business association & 11,00 & 5,70 & 34,00 & 9,00 & 6,82 & 58,00 \\
\hline & Other & 128,00 & 66,32 & 100,00 & 55,00 & 41,67 & 100,00 \\
\hline \multirow{6}{*}{$\begin{array}{l}\text { Source of skills } \\
\text { for running } \\
\text { the business }\end{array}$} & Training & 36,00 & 18,46 & 18,00 & 24,00 & 18,18 & 18,18 \\
\hline & Family & 33,00 & 16,92 & 35,00 & 36,00 & 27,27 & 45,45 \\
\hline & Friends & 67,00 & 34,36 & 69,00 & 44,00 & 33,33 & 78,78 \\
\hline & Past experience & 42,00 & 21,54 & 91,00 & 19,00 & 14,4 & 93,18 \\
\hline & Other & 16,00 & 8,21 & 99,00 & 9,00 & 6,82 & 100,00 \\
\hline & None & 1,00 & 0,51 & 100,00 & 0,00 & 0,00 & 100,00 \\
\hline \multirow{8}{*}{$\begin{array}{l}\text { Training } \\
\text { attended }\end{array}$} & Entrepreneurship & 46,00 & 52,27 & 52,00 & 41,00 & 67,21 & 67,21 \\
\hline & \begin{tabular}{|l} 
Marketing \\
\end{tabular} & 15,00 & 17,05 & 69,00 & 2,00 & 3,28 & 70,49 \\
\hline & $\begin{array}{l}\text { Human resource } \\
\text { Management }\end{array}$ & 0,00 & 0,00 & 69,00 & 0,00 & 0,00 & 70,00 \\
\hline & Sales management & 10,00 & 11,36 & 80,00 & 6,00 & 9,84 & 80,33 \\
\hline & Business planning & 6,00 & 6,82 & 87,00 & 3,00 & 4,92 & 85,25 \\
\hline & Financial management & 5,00 & 5,68 & 93,00 & 2,00 & 3,28 & 88,53 \\
\hline & $\begin{array}{l}\text { customer service } \\
\text { management }\end{array}$ & 5,00 & 5,68 & 99,00 & 6,00 & 9,84 & 98,36 \\
\hline & Other & 1,00 & 1,14 & 100,00 & 1,00 & 1,64 & 100,00 \\
\hline
\end{tabular}

Source: Primary data

The table above enables to note that males in Huye District are more involved in business than females since male business owners constitute $59.63 \%$ while female business owners constitute $39.37 \%$. The age group of 26-35years takes the highest number of business owners with $49.23 \%$ 
for male owners and $46.21 \%$ for female owners. The age group of over 55 years has the least number of business owners where males comprise $6 \%$ and females comprise $2 \%$.

Regarding educational qualification, male business owners having primary education level occupy the highest position with $43.59 \%$ followed by those having secondary education level with $31.28 \%$ while female business owners with secondary education level occupy the highest position with $42.43 \%$ followed by those having primary education level with $24.24 \%$. For marital status, married business owners occupy the highest position where females take higher percentage of $70.45 \%$ whereas males have $60 \%$. Yet for single business owners occupying the next position males have a higher percentage of $36.92 \%$ than that of $22.73 \%$ for females.

The business sector with attracting the highest number of business owners is trading where males have a higher percentage of $72.31 \%$ compared with $67.42 \%$ for females. It is followed by service sector where female business owners have a percentage of $18.94 \%$ higher than $14 \%$ for male business owners. Production sector attract the least number of business owners in Huye District. Of all business owners, those operating in sole proprietorships are far greater in number than those operating in partnerships and corporations combined. Females operating in sole proprietorship have a higher percentage of $96.21 \%$ than that of $94.87 \%$ for males. A higher number of businesses are operated in rented premises where males have a percentage of $84.62 \%$ higher than that of $81.82 \%$ for female business owners.

The results show that business owners in Huye District get business advice from different sources. Sources including business partner(s), husband, banks and business association are relied on by $33.68 \%$ of male business owners compared to $58.33 \%$ for female business owners. The other $66.32 \%$ of male and $41.67 \%$ of female business owners rely on other sources. These sources include the owners themselves, family members other than husbands, and friends.

Different sources of skills for running the business have been identified. Friends constitute the first source for both males with a percentage of $34.36 \%$ and females with a lower percentage of $33.33 \%$. However, the next source is past experience for males with a percentage of $21.54 \%$ whereas family is the next source for female with a percentage of $27.27 \%$. Males rely more on training than females do. 
The respondents have attended different trainings. Training in entrepreneurship occupies the highest position. Females have a percentage of $67.21 \%$ while male business owners have a lower percentage $52.27 \%$. Though they show small percentages, trainings in marketing, sales management, business planning, financial management and customer services management have been attended by both male female business owners.

\subsection{Entrepreneurial orientation of women and men business owners}

Table 3: Level of determination of entrepreneurial orientation by necessity and opportunity factors

\begin{tabular}{|c|c|c|c|c|}
\hline & \multicolumn{2}{|l|}{ Males } & \multicolumn{2}{|l|}{ Females } \\
\hline & Mean & $\begin{array}{l}\text { Mean } \\
\text { Ranks }\end{array}$ & Mean & $\begin{array}{l}\text { Mean } \\
\text { Ranks }\end{array}$ \\
\hline Necessity orientation & 2.25 & & 2.30 & \\
\hline Restructuring in my organization & 1,73 & 22 & 1,87 & 19 \\
\hline Downsizing in my organization & 1,7 & 23 & 1,77 & 20 \\
\hline Availability of secure job in the labor market & 2,73 & 13 & 3,09 & 11 \\
\hline Unemployment & 3,48 & 11 & 2,99 & 12 \\
\hline Underemployment & 2,24 & 16 & 2,19 & 17 \\
\hline Job with limited career advancement & 2,21 & 17 & 2,32 & 15 \\
\hline Lack of appreciation in the current job & 2,05 & 20 & 2,22 & 16 \\
\hline Dissatisfaction in prior job with respect to future career opportunities & 2,17 & 18 & 2,35 & 14 \\
\hline $\begin{array}{l}\text { Dissatisfaction in current job with respect to future career } \\
\text { opportunities }\end{array}$ & 2,16 & 19 & 2,42 & 13 \\
\hline Unrewarding relationship with co-workers & 1,79 & 21 & 1,65 & 21 \\
\hline Retirement occupation & 2,44 & 14 & 2,42 & 13 \\
\hline Opportunity orientation & 4.14 & & 4.26 & \\
\hline Experiencing better work-life balance & 4,15 & 3 & 4,27 & 3 \\
\hline Achieving personal independence & 4,08 & 4 & 4,25 & 4 \\
\hline Achieving economic independence & 3,98 & 6 & 4,25 & 4 \\
\hline Flexibility in running the business & 4,17 & 2 & 4,28 & 2 \\
\hline Making deference & 3,51 & 10 & 3,65 & 8 \\
\hline Expectation for more future benefits & 4,03 & 5 & 4,20 & 5 \\
\hline Making more money & 3,81 & 8 & 4,11 & 6 \\
\hline Tracking the work toward interests & 3,86 & 7 & 4,02 & 7 \\
\hline Continuation of business inherited from my family & 2,36 & 15 & 2,18 & 18 \\
\hline Filling the need of the market for new product/service & 3,45 & 12 & 3,53 & 9 \\
\hline Putting my skills into use & 3,54 & 9 & 3,52 & 10 \\
\hline Being self employed & 4,58 & 1 & 4,59 & 1 \\
\hline
\end{tabular}

Source: Primary data

From the table above, the results show that entrepreneurial orientation factors with a mean equal or greater than 4 are five including self employed, flexibility in running the business, 
experiencing better work-life balance, achieving personal independence and expectation for more future benefits with the respective mean 4.58, 4.17, 4.15, 4.08 and 4.03 for males. For females, eight factors have a mean equal or greater than 4 . These factors include being self employed, flexibility in running the business, experiencing better work-life balance, achieving personal independence, achieving economic independence, expectation for more future benefits, making more money and tracking the work toward interests with corresponding mean of 4.59, $4.28,4.27,4.25,4.25,4.20,4.11$ and 4.2 respectively. All the five entrepreneurial orientation factors identified for males are also included among eight factors with mean equal to or less than 4 indentified for females. It is worth mentioning that all these factors fall into opportunity orientation category.

The results also show that the five least ranking entrepreneurial factors include dissatisfaction in current job with respect to future career opportunities, lack of appreciation in the current job, unrewarding relationship with co-workers, restructuring in my organization, and downsizing in my organization with respective mean of 2.16, 2.05, 1.79, 1.73 and 1.7 for males. All these factors are found under the necessity orientation category. The five least ranking entrepreneurial factors for females include underemployment, continuation of business inherited from my family, restructuring in my organization, downsizing in my organization and unrewarding relationship with co-workers with respective mean of 2.19, 2.19, 1.87, 1.77 and 1.65. All these factors fall under the necessity orientation category except the continuation of business inherited from my family that fall under opportunity orientation.

The overall mean for necessity orientation comprises 2.25 and 2.30 values for males and female respectively while the overall mean for opportunity orientation comprises 4.14 and 4.26 values for both male and female respectively. This implies that both males and females more opportunity than necessity orientated. These findings concur with Bygrave, (2014) who said that a nation marks transition from less developed country to developing one there are more opportunities for employment and lead to decline of necessity - driven form of entrepreneurship. Yet, the findings disagree with Shane, (1992); Reynolds et al., (2002) and Hughes, (2003) who 
found out more necessity orientation on the side of women and opportunity orientation on the side of men.

\subsection{Women and men owned business performance}

Table 4. Levels of women and men owned business performance

\begin{tabular}{|c|c|c|c|c|}
\hline \multirow[b]{2}{*}{ Factors } & \multicolumn{2}{|l|}{ Males } & \multicolumn{2}{|l|}{ Females } \\
\hline & Mean & $\begin{array}{l}\text { Mean } \\
\text { Ranks }\end{array}$ & Mean & $\begin{array}{l}\text { Mean } \\
\text { Ranks }\end{array}$ \\
\hline \multicolumn{5}{|l|}{ Business performance } \\
\hline Financial performance & 3.94 & & 3.64 & \\
\hline Ability to generate sales revenue greater than our costs & 4.23 & 3 & 4.30 & 2 \\
\hline Growth of sales revenue over time & 3.95 & 8 & 4.01 & 8 \\
\hline Ablility to keep costs low enough to secure enough profit margin & 4.25 & 2 & 4.08 & 7 \\
\hline Ablility to make enough net profit from my business (profitability) & 3.86 & 10 & 3.87 & 10 \\
\hline Growth of net profit overtime & 3.63 & 11 & 3.73 & 11 \\
\hline $\begin{array}{l}\text { Ablility to repay our short term liabilities by means of our current } \\
\text { assets (liquidity) }\end{array}$ & 4.14 & 5 & 4.15 & 4 \\
\hline Availablity of enough cash to meet immediate requirement & 3.83 & 9 & 3.75 & 12 \\
\hline Ability to repay our long-term liabilities (solvency) & 3.33 & 12 & 3.51 & 13 \\
\hline Reliance on our personal funds more than borrowed funds (autonomy) & 4.13 & 6 & 4.14 & 5 \\
\hline $\begin{array}{l}\text { Anable to generate enough sales revenue by means of assets (assets } \\
\text { turnover) }\end{array}$ & 3.99 & 7 & 3.92 & 9 \\
\hline Non-financial performance & 3.29 & & 3.27 & \\
\hline Ablility to get maximum outputs from inputs used (efficiency) & 3.99 & 7 & 4.05 & 6 \\
\hline Ablility to get maximum outputs from employees & 3.21 & 13 & 3.31 & 14 \\
\hline Experiencing customer complaints & 3.04 & 14 & 2.76 & 16 \\
\hline Quick delivery of services/goods & 4.23 & 3 & 4.30 & 2 \\
\hline Experiencing returns of goods & 2.86 & 16 & 2.64 & 17 \\
\hline Getting new customers for our service /goods & 4.17 & 4 & 4.25 & 3 \\
\hline Experiencing employee turnover & 2.55 & 17 & 2.44 & 18 \\
\hline Ablity to meet the staff needs & 2.9 & 15 & 3.08 & 15 \\
\hline Experiencing frequent staff absences & 2.52 & 18 & 2.29 & 20 \\
\hline Loyality of customer to the business & 4.45 & 1 & 4.46 & 1 \\
\hline Provision of training to employees & 2.23 & 19 & 2.41 & 19 \\
\hline
\end{tabular}

Source: Primary data

The results in the table above indicate that both financial and non-financial aspects of business performance were examined. The factors having a mean equal or greater than 4 are seven including customer loyality, minimization of costs, quick delivery of goods/service, generation 
of sufficient sales revenue, getting new customer, liquidity, and financial autonomy with corresponding mean of $4.5,4.25,4.23,4.23,4.17,4.14$, and 4.13 respectively for males. For females, the factors having a mean equal or greater than 4 are nine including customer loyality, generation of sufficient sales revenue, quick delivery of goods/services, getting new customer, liquidity, financial autonomy, efficiency, minimization of cost and sales growth with corresponding mean of 4.46, 4.30, 4.30, 4.25, 4.15, 4.14, 4.09, 4.08, 4.05 and 4.01 respectively.

From seven top factors identified for males, four factors namely, minimization of costs, generation of sufficient sales revenue, liquidity, and financial autonomy are financial factors while the remaining three are non-financial factors. From top nine factors identified for females, five factors namely generation of sufficient sales revenue, liquidity, financial autonomy, minimization of cost and sales growth are financial performance factors whereas the remaining are non-financial performance factors.

According to the results in the very same table, it can also noted that the five least ranking performance factors include ability to meet staffs needs, returns of goods, employee turnover, frequency of staff absences and provision of training to employees with respective mean of 2.9, 2.86, 2.55, 2.52 and 2.23 for males whereas the five least ranking performance factors for females include ability to meet staffs needs, returns of goods, employee turnover, frequency of staff absences and provision of training to employees with respective mean of 2.76, 2.64, 2.44, 2.41 and 2.29. It is worth noting that all the five least ranking factors for both males and females are non-financial factors.

For financial performance, the results show the overall mean of 3.95 and 3.64 as mean for males and females respectively while the overall mean for non-financial performance are 3.29 and 3.27 for both male and female respectively. This implies that business owned by males perform better than business owned by females regarding both financial and non-financial performance aspects. This agree with Shim \& Eastlick, (1998) and Fisher et al.( 1993) who hold that businesses owned by male outperform business owned by female. 
4.3. Differences in the levels of determination of entrepreneurial orientation by necessity and opportunity factors

Table 5: Differences in the levels of determination of entrepreneurial orientation

\begin{tabular}{|l|r|r|r|r|}
\hline Gender & $\begin{array}{r}\text { Sum of } \\
\text { Squares }\end{array}$ & Mean Square & F & Significance \\
\hline Between & 0.484 & 0.484 & 3.529 & 0.061 \\
$\begin{array}{l}\text { Groups } \\
\text { Within }\end{array}$ & 44.568 & 0.137 & & \\
Groups & & & \\
Total & 45.052 & & & \\
\hline
\end{tabular}

Source: Primary data

The results in table 5 indicate a level of significance of 0.061 . This means that, as per Gerard Keller (2015)'s interpretation, there are no significant differences in the levels of determination, by necessity and opportunity factors, of entrepreneurial orientation between men and women owning business in Huye District. This leads to the confirmation of the hypothesis stating that there is no significant difference in the levels of determination, by necessity and opportunity factors, of entrepreneurial orientation between men and women owning businesses in Huye District.

\subsection{Differences in the levels of women and men owned business performance}

Table 6: Differences in the levels of business performance

\begin{tabular}{|l|r|r|r|r|}
\hline & \multicolumn{1}{|c|}{$\begin{array}{c}\text { Sum of } \\
\text { Squares }\end{array}$} & $\begin{array}{c}\text { Mean } \\
\text { Square }\end{array}$ & F & Sig. \\
\hline Between Groups & 0,227 & 0,227 & 1,333 & 0,249 \\
Within Groups & 55,456 & 0,171 & & \\
Total & 55,684 & & & \\
\hline
\end{tabular}

Source : Primary data

From table 6 it can be noted that a level of significance of 0.249. According to Gerard Keller (2015)'s interpretation, this implies that there is no significant difference in the levels of business 
performance between men and women owned business in Huye District. This leads to the confirmation of the hypothesis stating that there is no significant difference in the levels of business performance between men and women owned businesses in Huye District.

\subsection{Correlation analysis}

Table 7 : Pearson's correlation analysis of independent vs dependent variables

\begin{tabular}{|c|c|c|c|}
\hline & & $\begin{array}{l}\text { Information } \\
\text { about } \\
\text { entrepreneuri } \\
\text { al orientation }\end{array}$ & $\begin{array}{l}\text { Information about business } \\
\text { performance }\end{array}$ \\
\hline $\begin{array}{l}\text { Information about } \\
\text { entrepreneurial } \\
\text { orientation }\end{array}$ & $\begin{array}{l}\text { Pearson } \\
\text { Correlation } \\
\text { Sig. (2-tailed) } \\
\text { N }\end{array}$ & 327 & .001 \\
\hline $\begin{array}{l}\text { Information about } \\
\text { business performance }\end{array}$ & $\begin{array}{l}\text { Pearson } \\
\text { Correlation } \\
\text { Sig. (2-tailed) } \\
\text { N }\end{array}$ & .001 & $\begin{array}{r}1 \\
327 \\
\end{array}$ \\
\hline
\end{tabular}

**. Correlation is significant at the 0.01 level (2-tailed).

\section{Source: Primary data}

Results in table 7 indicate 0.327 as Pearson's correlation coefficient at the significance level of 0.001. This coefficient, according to Gerard Keller (2015), implies significant relationship between the two variables. Since the level of significance is less than 0.01 , the hypothesis stating that there is no significant relationship between entrepreneurial orientation of women and men business owners and their business performance is rejected. Therefore, it can be inferred that there is a significant relationship between these two variables. This relationship then imply that the women and men entrepreneurial orientation influence either positively or negatively their business performance.

\section{Recommendations and Research Contribution}


Statistical findings of this research show that there is gender unbalance as far as starting business is concerned. This unbalance continued to their business performance where male performs better than their female counterpart. This led us to recommend the government to emphasis on trainings and sensitizing female to start their own businesses for linking their economic, household and family development through entrepreneurship. Encouraging female to embark in entrepreneurship will also reduce a serious problem of unemployment as it represents a high rank of 12 compare to 11 for male, as the reasons to start business.

Education was found to increase the business creation among women and men; this finding should be taken as a key contributor to the development of education as one of the vision 2050 objectives. This serves as motivator to the Ministry of Education to construct practical and relevant programs in entrepreneurship for potential entrepreneurs; specifically the two first levels (primary and secondary).

Moreover, this study contributes to the knowledge differently. One hand it contributes to the literature on the influence of gender on entrepreneurial orientation (necessity/opportunity) and on business performance in developing country like Rwanda. On the other hand, by highlighting that entrepreneurship attitude is not one perspective; but combines push and pull factors. This contributes mostly on the awareness of the two perspectives: necessity / opportunity related to gender.

BDF, RDB and the Districts should work more closely to attract and sensitize new business in production and agriculture sectors for the purpose of creating more employment on one side and transforming subsistence-based agriculture to market-oriented farming. This will increase productivity and satisfy local and overseas market; in addition to that Rwanda will benefit with those sectors during the African Continental Free Trade area soon launched.

\section{Limitations and Further research}

The current study has some limitations related to the availability of information regarding business ownership at district level. It was noted that out of 14 sectors found in Huye District, only business owners related data from 11 sectors were available. This prevented the researchers 
to cover the entire Huye District and narrowed the geographical scope. The findings of this research would have been improved by another research about comparative study of entrepreneurial orientation among Rwanda business owners to non-Rwandan business owners operating in Rwanda. Researchers can extend and verify our findings countrywide for capturing the hall country information. Finally, more background on necessity/opportunity orientation factors should be studied and reassessed confirms this research results and implications.

\section{References}

1. Allen, I.E., A. Elam, N. Langowitz, and M. Dean. 2007. Global Entrepreneurship Monitor (GEM) Report on Women Entrepreneurs. The Center for Women's Leadership, Babson College. Available from World Wide Web:

www3.babson.edu/CWL/upload/GEMWomen07.pdf

2. Alsos, G., and E. Ljunggren. 1998. "Does the Business Start-up Process Differ by Gender? A Longitudinal Study of Nascent Entrepreneurs." In P. Reynolds, W. Bygrave, N. Carter, S. Manigart, C. Mason, G. Meyer, and K.Shaver (eds.), Frontiers of Entrepreneurship Research. Babson College: Babson Park, MA.

3. Anna, L., G. Chandler, E. Jansen, and N. Mero. 2000. "Women Business Owners in Traditional and Nontraditional Industries." Journal of Business Venturing 15(3): 279-303.

4. Bandura. A. 1997. Self-efficacy. The exercise of control. New York: Freeman \& Co.

5. Bates, T.M. 1997. Race, Self-employment and Upward Mobility: An Illusive American am. The Woodrow Wilson Center Press: Washington, DC.

6. Belcourt, M. 1990. “A Family Portrait of Canada's Most Successful Female Entrepreneurs." Journal of Business Ethics 9(4/5): 435-438.

7. Cooper, A.C \& Gascon, E.J.G.1992. Entrepreneurs, processes of founding, and new-firm performance, in The state of art of entrepreneurship, edited by DL Sexton \& JD Kassadra. Boston: PWS-Kent.

8. De Freitas, G. 1991. Inequality at Work: Hispanics in the U.S. Labor Force. Oxford University Press: New York, NY.

9. Fischer, E.M., A.R. Reuber, and L.S. Dyke. 1993. "A Theoretical Overview and Extension of Research on Sex, Gender and Entrepreneurship." Journal of Business Venturing 8: 151-168.

10. Gatewood, E.J., K.G. Shaver, and W.B. Gartner. 1995. "A Longitudinal Study of Cognitive Factors Influencing Start-up Behaviors and Success at Venture Creation.” Journal of Business Venturing 10(5): 371-391.

11. Gerard Keller (2015). Statistics for management and economics, $10^{\text {th }}$ Ed., South-Western Cengage Learning, United State of America. 
12. Government of Rwanda (GoR) (2014). Economic Development and Poverty Reduction Strategy. Kigali: GoR.

13. Jean Bosco Shema and Mutarindwa Samuel. 2017. "Women's entrepreneurship in Rwanda: overcoming entrepreneurial stereotypes through government support." Marcela Ramírez-Pasilla, Ethel Brundin and Magdalena Markowska - 9781785367526. Downloaded from Elgar Online at 07/27/2017 03:43:50PM via Jönköping University

14. Kariv, D. 2008. "Entrepreneurial Orientations of Women Business Founders from a Push/Pull Perspective: Canadians versus non-Canadians-A Multinational ssessment." Journal of Small Business and Entrepreneurship 24.3 (2011): pp. 397-425.

15. Kariv, D., T. Menzies, G. Brenner, and L.J. Filion. 2009. "Ethnic Entrepreneurs in Canada: Transnational Networking and Business Success." Entrepreneurship and Regional Development 21(3): 239-264.

16. Kirzner, I. 1973. Competition and Entrepreneurship. University of Chicago Press: Chicago, IL.

17. Klyver, K., S.L. Nielsen, and M. Rostgaard Evald (2013).Women's self-employment: an act of institutional (dis)integration? A multilevel, cross-country study, Journal of Business Venturing, 28(4): 474-488.

18. Krejcie, R. V. and Morgan, D.W. (1970). Determining Sample Size for Research Activities, Educational and Psychological Measurement, 30, pp 607-610

19. Langowitz, N., and I.E. Allen. 2006. "The Top Woman-led Businesses in Massachusetts: 2006 Results.” The Center for Women's Leadership at Babson College: Boston, MA.

20. Li, Y.H, Huang, J.W \& Tsai, M.T. 2009. Entrepreneurial orientation and company performance: The role of knowledge creation process. Industrial Marketing Management 38(209):440-449.

21. Lumpkin, G.T \& Dess, G.G. 2001. Linking two dimensions of entrepreneurial orientation to business performance: The moderating role of environment and industry life cycle. Journal of Business Venturing 16:429-451.

22. Murphy, G.B., Trailer, J.W. \& Hill, R. 1996. Measuring performance in entrepreneurship research. Journal of Business Research. Vol.36(1): pp15-23.

23. OECD. 2005. SME and Entrepreneurship Outlook-2005 Edition. Available from World Wide Web: www.oecd. org/document/15/0,3343,en_2649_34197_35096847_1_1_1_1,00.html 24. Reynolds, P., W.D. Bygrave, and E. Autio. 2004. Global Entrepreneurship Monitor2004 Executive Report. Kauffman Center for Entrepreneurial Leadership: Kansas City, MO.

25. Reynolds, P.D., S.M. Camp. W.D. Bygrave, E. Autio, and M. Hay. 2002. Global Entrepreneurship Monitor-2001 Executive Report. Babson College: Boston, MA; London Business School: London, UK.

26. Ritsilä, J., and H. Tervo. 2002. Effects of Unemployment on New Firm Formation: Micro Level Panel Data Evidence from Finland." Small Business Economics 19(1): 31-40. 
27. Riverin, N., and L.J. Filion. 2005. Global Entrepreneurship Monitor (GEM) Canadian National Report 2005. Available from World Wide Web: http://neumann.hec.ca/chaire.entrepreneuriat/Projets\%20en\%20cours/ GEM/Articles/Rapp_GEM_2005_angl.pdf

28. Shane, S.A. 1992. "Why Do Some Societies Invent More Than Others?" Journal of Business Venturing 7: 29-46.

29. Shim, S., \& Eastlick, A. (1998). Characteristics of Hispanic femalebusiness owners: An exploratory study. Journal of SmallBusiness Management, 36(3), 18-54.

30. Simon Radipere. 2014. "The Effects of Entrepreneurial Orientation on Business Performance." Mediterranean Journal of Social Sciences. DOI: 10.5901/mjss.2014.v5n16p141 31. Wiklund, J., and D. Shepherd. 2003. "Knowledge-based Resources, Entrepreneurial Orientation, and the Performance of Small and Medium-sized Businesses." Strategic Management Journal 24(13): 1307-1314. 